\title{
DOUBLE BROODS OF TREE SWALLOWS IN ONE NEST BOX
}

DON STILES, 20 Lake Wapta Rise SE, Calgary, Alberta. T2J $2 \mathrm{M} 9$ and GRACE NEILL, Box 727, Stettler, Alberta. TOC 2LO

On 13 June 1982, while monitoring on the East Didsbury bluebird trail, Don Stiles, Philip Stiles and Dan Cloutier discovered a Tree Swallow nest with 12 eggs at house No. 143, $20 \mathrm{mi}(32 \mathrm{~km})$ east of Didsbury. The eggs were clean and fresh looking and the nest was active with an adult brooding, which was banded. On previous occasions where large numbers of Tree Swallow eggs were found, the nest was unmade, the eggs were dirty and no subsequent hatchings occurred. In this case, on the next monitoring, on 1 July, there were 12 healthy looking young. All were banded. Two days later, they were photographed, and a decision was made to leave all 12 in the nest and not move some to nearby boxes as they seemed to be folding themselves over one another to avoid taking up the whole box. A final check on 20 July suggested all had fledged successfully. Three adults flying around the nest on 13 June and 1 July, and five adults flying around on 3 July lead us to believe it was a multiple effort which fledged the 12 Tree Swallows in one box.

At the September meeting of the Federation of Alberta Naturalists, conversation with Grace Neill of Stettler revealed that she too had found a similar situation.

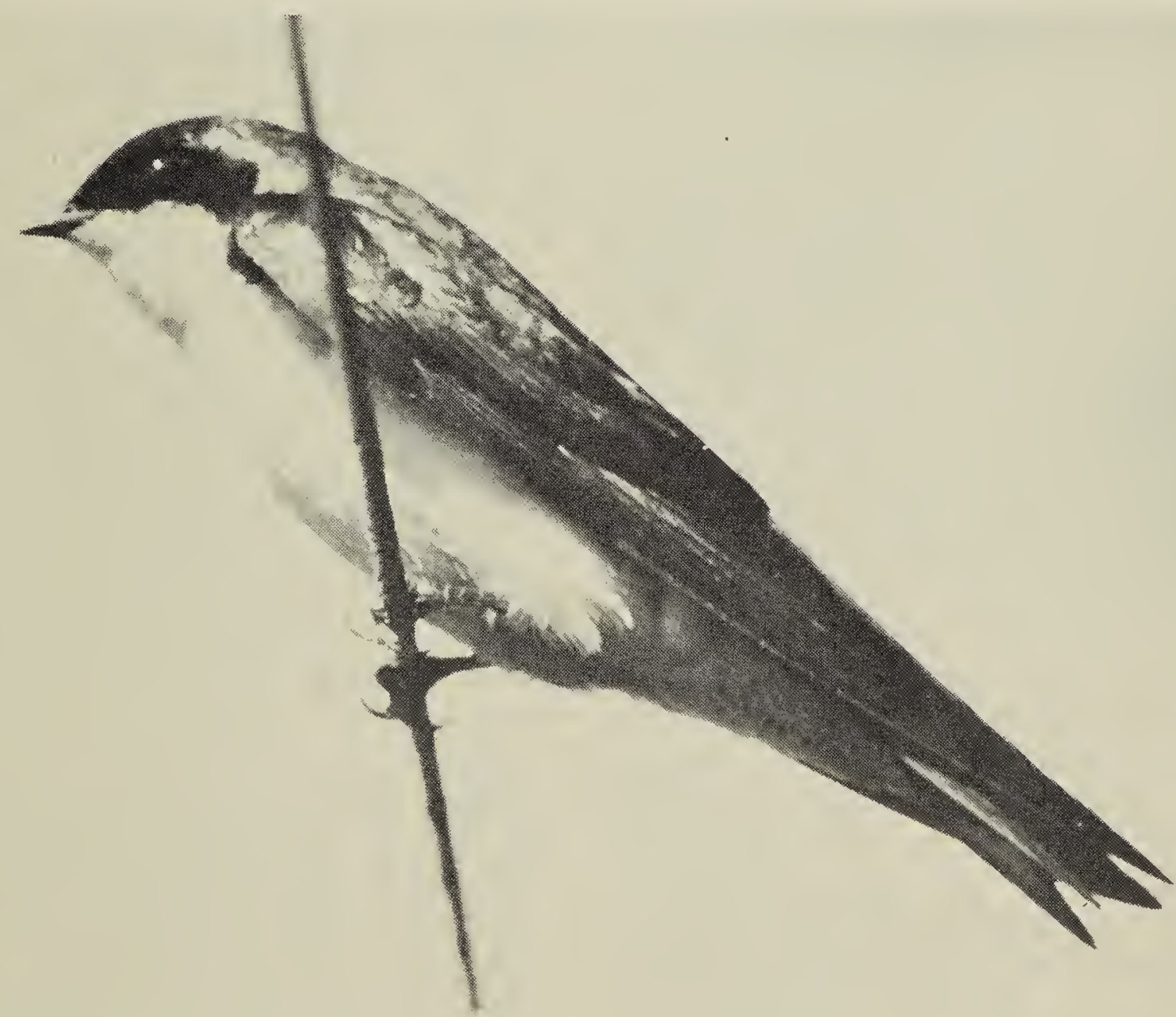


She has just a few nest boxes around her farm, four mi South of Stettler. When Tree Swallows took possession of house No. 7, several birds were seen flying around it. The first egg was found on 15 May. On 30 May there were 13 eggs, with two hens brooding them. Both hens flew. On 12 June, one hen flew out as Grace looked in. The other one was lifted, the eggs counted and the hen put back down on the nest. She stayed there! On 15 June, when Lloyd Lohr came along to see the nest, the eggs were hatching. Lloyd noted then that there was only one male bird near, and concluded that here was a case of polygamy. A few days later three infertile eggs were removed from the nest and the ten young birds left alone for quite some time. When the house was next checked there were the remains of two nearly fully grown birds. The rest, presumably, had flown.

Inquiries revealed that Blake Stillings of Calgary encountered a case in 1978, the first year he started his bluebird trail, where 9 tree swallow young had fledged from a single nest. There were two hens on the nest brooding 9 eggs and a male nearby, suggesting polygamy. Although Blake has built his trail to over 300 boxes, a similar situation hasn't appeared since.

The authors would be interested in learning if others have run across similar double brood situations.

\section{EFFECTS OF A LATE MAY SNOW- STORM ON MOUNTAIN BLUEBIRD AND TREE SWALLOW NESTING}

\section{MARY I. HOUSTON, 863 University Drive, Saskatoon, Saskatchewan: S7N 0J8}

Each April, with the help of willing assistants, I check the 240 boxes on the actively maintained section of the Saskatoon Junior Natural History Society's Bluebird Trail within $60 \mathrm{~km}$ of Saskatoon. Damaged boxes are repaired or replaced to be ready for occupancy by the returning Mountain Bluebirds.

Banding of young Mountain Bluebirds usually gets underway in late May. For example, in 1980 I banded young at 8 nests on 27 May, and at 16 nests on 29 May, continuing on throughout the summer with second nestings in 27 of the 59 boxes used by bluebirds. The last young were banded on 17 July. In a total of 84 nestings, 324 young bluebirds were banded.
In 1981, young from 13 nests were banded on 30 May and those from another 20 nests on 31 May. The last young bluebirds were banded on 21 July. A total of 71 boxes was used by bluebirds and 36 were used for second nestings, for an overall total of 107 nestings and 355 young banded.

In contrast, the 1982 nesting statistics were very different, due largely to the disturbance caused by the unseasonably heavy snowfall $(15.4 \mathrm{~cm})$ on 28 May and the subsequent cold days without apparent insects for food. Only 2 bluebird nests survived the storm, with the first bluebird brood of 4 young banded on 7 June, and a second brood of 6 on 16 June. Even these clutches were 1 and 2 weeks late, compared to 